\title{
O MEIO AMBIENTE COMO DIREITO DIFUSO E A SUA PROTEÇÃO COMO EXERCÍCIO DE CIDADANIA
}

\section{THE ENVIROMENT AS COLETIVE RIGHT AND YOUR PROTECTION AS CITIZENSHIP EXERCISE}

Adriano Stanley Rocha Souza ${ }^{1}$

\section{Resumo}

O presente trabalho tem por fim analisar a evolução legislativa pela qual passou o meio ambiente.

Cuidaremos de demonstrar que a preocupação ambiental somente surge no Brasil a partir da década de 60 e, mesmo assim, graças às pressões internacionais que o mundo passou a sofrer, principalmente, após a criação do Clube de Roma, em 1972.

Fator de primordial importância na evolução da proteção do meio ambiente no Brasil, foi a sua elevação a "bem de uso comum do povo", ou seja: a sua elevação a bem jurídico. E, mais que isto, o tratamento que recebeu da Constituição da República como sendo um bem de interesse difuso.

Desta forma, abriu-se a possibilidade de que a defesa do meio ambiente não fique adstrita ao Ministério Público, mas transcenda a todos aqueles que desejarem exercer a sua defesa, o que contribuiria para maior fiscalização e zelo com a questão ambiental.

Infelizmente, entretanto, a grande maioria do povo brasileiro ainda não tomou a consciência de que, ao cuidar daquilo que pertence a todos, estaremos cuidando do que nosso. Que este trabalho ajude na conscientização de se proteger o meio ambiente de maneira coletiva.

Palavras-chave: Meio-ambiente, Constituição, Ação Civil Pública, Ação Popular, Cidadania.

\section{A EVOLUÇÃO DAS NORMAS AMBIENTAIS NO BRASIL}

Enfim, a comunidade jurídica nacional se desperta da letargia de que era dominada ao longo da sua história no que se refere à preocupação de um dos maiores patrimônios nacionais: o meio ambiente.

Até a promulgação da Constituição da República de 1988, as normas relativas à preocupação ambiental eram escassas. Eram regras secundárias nas autorizações e licenças administrativas outorgadas, onde se confundiam como meros requisitos ao licenciamento, como se fossem uma variante do Direito Administrativo.

Quando muito, eram normas infra-constitucionais elaboradas em diferentes períodos da história nacional, com preocupações díspares e desarmônicas, cada qual cuidando da proteção de recursos naturais diferentes, não se podendo falar na existência de um conjunto de

\footnotetext{
1 Mestre e Doutor em Direito Processual pela Puc Minas. Professor de Pós-graduação nos níveis de Mestrado e Doutorado em Direito Privado. Professor de graduação de Direito Civil na PUC MINAS E UNIFEMM.
} 
normas legais com a mesma filosofia, que tivessem por escopo a preservação do meio ambiente como um todo, que levassem em consideração toda a complexidade que é peculiar à matéria.

Tal despreocupação com a questão ambiental encontra explicação em fatores de variados matizes: científico, político, econômico e, até mesmo, sociológico.

Até o início do século passado ainda vigia o pensamento, herdado de séculos anteriores (em especial do final do século XIX), de que o desenvolvimento material das sociedades era o valor supremo a ser almejado. Desconsiderava-se por completo a possibilidade de que o processo industrial pudesse conter em si algum malefício, fruto do lixo industrial, que fosse capaz de prejudicar a natureza. Natureza esta, que sendo compreendida pelos homens daquela época como uma dádiva, talvez fosse capaz de absorver, de forma integral, todos os resíduos que as atividades industriais viessem a produzir, sem que com isto sofresse qualquer consequiência.

Seguramente, a inexistência de problemas ambientais agudos, àquela época, levava os homens a "um entendimento generalizado de que a natureza seria capaz de absorver materiais tóxicos lançados ao meio ambiente, e, por um mecanismo 'natural' (talvez 'mágico'?!), o equilíbrio seria mantido de maneira automática" ${ }^{2}$.

A comunidade científica foi a primeira a perceber a urgência em se adotar medidas de proteção ao meio ambiente a fim de se preservar o planeta e, por conseguinte, a espécie humana. Ainda assim, tal despertar se dera somente depois da segunda metade do século XX, mais precisamente após 1960, quando as comunidades científicas nacional e internacional intensificaram as suas atividades no sentido de conscientizar os povos dos riscos e dos prejuízos que o planeta já havia experimentado e ainda estava a suportar ${ }^{3}$.

A despeito do vanguardismo que os movimentos ambientalistas representaram à época, a tomada desta consciência já fora, de certa forma, tardia, levando-se em conta a grande destruição e, em alguns casos, a perda total de muitos ecossistemas inteiros, de todas as partes do globo.

Somente depois de intenso trabalho de conscientização pública ${ }^{4}$, levada a cabo por comunidades inteiras de cientistas e ambientalistas, alguns países se despertaram para a

2 SOARES, Guido Fernando Silva. Direito Internacional do Meio Ambiente. Emergência, Obrigações e Responsabilidades. São Paulo. Ed. Atlas. 2001. p. 35

3 BARACHO JÚNIOR, José Alfredo de Oliveira. Responsabilidade Civil por Dano ao Meio Ambiente. Belo Horizonte. Ed. Del Rey. p. 175

4 "Resultado de tal conscientização, e como reflexo das exigências da opinião pública internacional, em 1972, a ONU convocaria a citada conferência em Estocolmo, tida como um dos marcos do Direito Internacional do Meio Ambiente, especialmente dedicada ao Meio Ambiente Humano, da qual resultaria a instituição, no 
necessidade de se criar mecanismos hábeis a proteger os seus ecossistemas. Merece destaque, neste período, os trabalhos realizados pelo chamado "Clube de Roma, como um indicador da preocupação de cientistas, industriais e empresários com o meio ambiente" 5.

No caso brasileiro, tal consciência só veio a ganhar maior força no final do século XX, com a promulgação da Constituição da República de 1988, que destinou um capítulo inteiro ao Meio Ambiente (Capítulo VI, do Título VIII).

Com este tratamento constitucional, teve início no Brasil, finalmente, a preocupação política com a questão ambiental.

Pela primeira vez na história constitucional brasileira, os constituintes voltavam suas atenções para temas que até então eram reservados aos, ambientalistas, biólogos, geólogos, e outros doutores das ciências naturais.

Tal destaque constitucional à matéria ambiental, contudo, só foi possível, ou mesmo provocado, graças aos níveis de industrialização e econômico em que já se encontrava o Brasil no início da década de 80. Isto porque, como bem salientado nas palavras de José Alfredo de Oliveira Baracho Júnior:

\begin{abstract}
A discussão de problemas ambientais só é possível em uma sociedade industrializada, seja porque nelas a organização de interesses metaindividuais se torna viável, seja porque os problemas ambientais se tornam mais acentuados com a industrialização.

Quando os problemas ambientais se apresentaram de forma grave para a sociedade moderna, o Brasil ainda estava em um processo incipiente de industrialização, e os interesses metaindividuais que estavam sendo organizados diziam respeito às relações de trabalho. Além disso, a massa de pessoas excluídas do processo de modernização da sociedade brasileira era muito grande para ser desconsiderada, o que tornava prioritária no Brasil a preocupação com o desenvolvimento. ${ }^{6}$
\end{abstract}

Portanto, não é errado dizer que a questão ambiental, no Brasil, somente encontrou campo fértil após superadas as barreiras da industrialização e do desenvolvimento econômico nacionais.

Aliás, outro fator preponderante para o trato constitucional da matéria ambiental refere-se, exatamente, ao conteúdo econômico que a moderna sociedade capitalista descobriu

sistema das Nações Unidas, do Programa das Nações Unidas para o Meio Ambiente, o Pnuma, entidade com sede em Nairóbi, capital do Quênia".

SOARES, Guido Fernando Silva. Direito Internacional do Meio Ambiente. Emergência, Obrigações e Responsabilidades. São Paulo. Ed. Atlas. 2001. p. 37

5“O 'Clube de Roma' financiou o trabalho 'Limites do Crescimento' (Limits to growth), também conhecido como Relatório Meadows, produzido por uma equipe de especialistas do Massachusetts Institute of Tecnology

- MIT, no qual se buscava apontar a extensão e a natureza dos principais problemas ambientais, utilizando-se um modelo cibernético da realidade do planeta. O documento causou grande impacto, tomando-se uma referência do movimento ambientalista na década de 70" 5. BARACHO JÚNIOR, José Alfredo de Oliveira.Op. cit. p. 175

6 Idem. p. 179

Revista da Faculdade Mineira de Direito, v.13, n. 25, jan./jun. 2010 - ISSN 1808-9429. 
no meio ambiente após a segunda metade do século XX. Este conteúdo foi outro fator que despertou na classe política brasileira a necessidade de resguardar aquele que é um dos maiores patrimônios ecológicos do mundo.

Note-se que, não obstante a importância do meio ambiente como elemento essencial à vida, o fator decisivo para a inclusão do meio ambiente como matéria constitucional foi a percepção, pela classe política brasileira, de que o meio ambiente estava ganhando espaço privilegiado na sociedade moderna, assumindo papel de destaque no cenário econômico: o "petróleo verde" (numa alusão à crise do petróleo sofrida pelo mundo na década de 70, em que este fora o recurso natural mais visado, como ocorre hoje com o meio ambiente).

É importante destacar por fim, que as mudanças ocorridas na consciência nacional foram além do trato constitucional e do aumento de normas atinentes à matéria. Houve mesmo, uma mudança de mentalidade no trato com o meio ambiente:

\footnotetext{
A forma como as normas brasileiras protegiam os elementos naturais até a década de 70 considerava o meio ambiente como 'recurso', ou seja, como um meio para a obtenção de finalidades humanas.

Bastante ilustrativas do paradigma daquela época são as palavras de Pereira, que na década de 50 escreveu uma obra na qual analisava o primeiro Código Florestal:

'A importância das florestas para a vida humana tem sido ressaltada, em copiosa literatura, através dos tempos. Ninguém ignora já hoje que onde não há florestas as condições favoráveis de vida se reduzem ao mínimo, em face da extensão e do volume consumido da matéria-prima que elas oferecem: a madeira. Daí a necessidade de uma atividade florestal plena, capaz de entreter o rendimento das florestas à altura das solicitações da indústria.'

Com o incremento das normas ambientais no Brasil, o meio ambiente deixou de ser tratado como 'recurso'.
}

Esta conscientização levou o legislador brasileiro à construção de mecanismos jurídicos hábeis a proteger o seu patrimônio ambiental. Dentre estes mecanismos, destaque-se a Lei de Crimes Ambientais (Lei no 9.605 de 12 de fevereiro de 1998), no âmbito criminal, bem como a instituição da responsabilidade civil objetiva (no âmbito cível), pelos danos cometidos ao meio ambiente.

\subsection{O meio ambiente na Constituição de 1988: bem (jurídico) de uso comum do povo}

Coroando a evolução da consciência de preservação ambiental pela qual passou o Brasil a partir da década de 60, a Constituição da República de 1988 confere ao meio ambiente o status de bem jurídico.

Assim dispõe a Constituição da República em seu artigo 225, caput:

7 BARACHO JÚNIOR, José Alfredo de Oliveira. Op. cit. p. 183

Revista da Faculdade Mineira de Direito, v.13, n. 25, jan./jun. 2010 - ISSN 1808-9429. 
Art. 225 - Todos têm direito ao meio ambiente ecologicamente equilibrado, bem de uso comum do povo e essencial à sadia qualidade de vida, impondo-se ao Poder Público e à coletividade o dever de defendê-lo e preservá-lo para as presentes e futuras gerações (grifos nossos) ${ }^{8}$.

Com efeito, pela primeira vez na história legislativa brasileira o meio ambiente é reconhecido como um bem, dotado de valor econômico e social, e cuja proteção e preservação são confiadas, textualmente, ao Poder Público e a toda a coletividade. Vale destacar ainda a expressão "para as presentes e futuras gerações", numa singular e louvável preocupação do legislador constitucional em garantir ao meio ambiente uma proteção tal que transcenda os limites temporais.

A classificação do meio ambiente como sendo um bem jurídico não é mera questão conceitual. Ganha conotação prática de alta relevância processual quando compreendida sob o prisma da teoria geral do Direito onde: só aquilo que a ordem jurídica reconhece como sendo $b e m^{9}$, pode ser objeto de direito. E só o objeto de direito pode ser objeto das relações jurídicas.

Portanto, enquanto o meio ambiente não era compreendido como bem jurídico, mas simplesmente como algo sem qualquer valoração econômica (como o amor, a saudade, a natureza, etc.), ou como um fator externo à vida humana; como uma espécie de "dádiva" oferecida aos homens (entendimento este que perdurou até meados do século XX, como visto alhures) ${ }^{10}$, o mesmo não era considerado como objeto de direito, ficando assim, fora das relações jurídicas.

Consequiência direta de tal fato era a grande fragilidade a que eram expostas as questões ambientais no Brasil já que, não sendo o meio ambiente considerado um bem em si, não poderia ser objeto de direitos. E, não sendo objeto de direitos, ninguém poderia exercer a sua proteção por faltar a este interessado uma das condições da ação, a saber: a possibilidade jurídica do pedido. Como pedir a proteção jurídica de algo que não é tutelado pelo direito?

8 BRASIL. Constituição da República Federativa do Brasil. 29. ed. atual. e ampl. São Paulo. Saraiva. 2002

9 "São bensjurídicos, antes de tudo, os de natureza patrimonial. Tudo que se pode integrar no nosso patrimônio é um bem, e é objeto de direito subjetivo. São os bens econômicos. Mas não somente estes são objeto de direito. A ordem jurídica envolve ainda outros bens inestimáveis economicamente, ou insuscetíveis de se traduzirem por um valor pecuniário. Não recebendo, embora, esta valoração financeira, e por isso mesmo não integrando o patrimônio do sujeito, são suscetíveis de proteção legal. Bens jurídicos sem expressão patrimonial estão portas adentro do campo jurídico; o estado de filiação, em si mesmo, não tem expressão econômica; o direito ao nome, o poder sobre os filhos não são suscetíveis de avaliação. Mas são bens jurídicos, embora nãopatrimoniais. Podem ser, e são, objeto de direito. Sobre eles se exerce, dentro dos limites traçados pelo direito positivo, o poder jurídico da vontade, e se retira da incidência do poder jurídico da vontade alheia". PEREIRA, Caio Mário da Silva. Iinstituições de Direito Civil. Rio de Janeiro. Forense. 1991. p. 272

10 SOARES, Guido Fernando Silva. Direito Internacional do Meio Ambiente. Emergência, Obrigações e Responsabilidades. São Paulo. Ed. Atlas. 2001. p. 37

Revista da Faculdade Mineira de Direito, v.13, n. 25, jan./jun. 2010 - ISSN 1808-9429. 
Não estamos dizendo que o meio ambiente era desprovido de qualquer instrumento para sua proteção. Como já dito acima, até a promulgação da Constituição de 1988 existiam várias normas de proteção aos mais diversos recursos naturais: Código de Águas, Código Florestal, o Estatuto da Terra, dentre outros. Entretanto, tais normas tinham por objeto a proteção de recursos naturais específicos e não o meio ambiente como um todo, como hoje o concebemos.

E, ainda assim, eram normas que visavam à proteção dos "recursos" naturais, como já acima comentado, antes no sentido de se garantir que tais "recursos" não fossem de tal forma agredidos a ponto de se ameaçar as atividades econômicas deles dependentes (estas sim, objeto direto da proteção legal), do que necessariamente protegê-los como O BEM em si mesmo considerado. Ou seja: protegiam-se os recursos naturais como meio para se proteger as atividades econômicas destes dependentes. Portanto, o bem jurídico que aquelas normas ambientais visavam a proteger era mais as atividades econômicas que o meio ambiente em si mesmo.

Tome-se por exemplo, o decreto $\mathrm{n}^{\mathrm{o}} 23.777$ de 23.01.1934 que regularizava o lançamento de resíduos industriais das usinas açucareiras nas águas fluviais. Este decreto, em seus artigos $1^{\circ}$ e $2^{\circ}$ dispõem o seguinte:

\footnotetext{
Art. $1^{\circ}$ - Fica estabelecida a obrigatoriedade do lançamento dos resíduos industriais das usinas açucareiras nos rios principais, longe das margens, em lugar fundo e correntoso.

Art. $2^{\circ}$ - Quando não seja possível o cumprimento do disposto no artigo anterior, ficam as mesmas usinas açucareiras obrigadas a adotar tanques de depuração, podendo, então, proceder ao escoamento do líquido depurado nos pequenos cursos d'água, nas lagoas ou em quaisquer águas paradas. (grifos nossos)
}

Não há como negar que tais artigos já demonstram uma certa preocupação com a preservação dos recursos hídricos próximos às usinas açucareiras. Entretanto, tal preservação constituiria mero meio para se proteger um bem principal: a atividade açucareira, já que, o comprometimento dos recursos hídricos próximos às usinas, fatalmente, implicaria na paralisação destas.

Note-se que os artigos supra referidos preocupavam-se antes, em definir como seria a descarga dos subprodutos da atividade açucareira que, necessariamente, preservar os recursos hídricos, já que o parágrafo $2^{\circ}$ chegava mesmo a permitir que o "líquido depurado" fosse jogado nas lagoas ou em quaisquer águas paradas, não demonstrando o legislador qualquer preocupação quanto à possibilidade de que tais lagoas ou águas paradas se tornassem fossas a céu aberto. 
Vide, ainda, o Código de Águas (Decreto 24.643, de 10 de julho de 1934). Esta legislação dispunha acerca da proteção dos recursos hídricos isoladamente considerados, com conotação altamente econômica. Tome-se, por exemplo, o artigo 73 deste diploma legal:

\begin{abstract}
Art. 73. Se o prédio é simplesmente banhado pela corrente e as águas não são sobejas, far-se-á a divisão das mesmas entre o dono ou possuidor dele e o do prédio fronteiro, proporcionalmente a extensão dos prédios e as suas necessidades.

Parágrafo único. Devem-se harmonizar, quanto possível, nesta partilha, os interesses da agricultura com os da indústria; e o juiz terá a faculdade de decidir "ex-bono et aequo" (grifos nossos).
\end{abstract}

Ou ainda, os artigos 109 a 112 do mesmo diploma legal:

Art. 109. A ninguém é lícito conspurcar ou contaminar as águas que não consome, com prejuízo de terceiros.

Art. 110. Os trabalhos para a salubridade das águas serão executados á custa dos infratores, que, além da responsabilidade criminal, se houver, responderão pelas perdas e danos que causarem e pelas multas que lhes forem impostas nos regulamentos administrativo.

Art. 111. Se os interesses relevantes da agricultura ou da indústria o exigirem, e mediante expressa autorização administrativa, as águas poderão ser inquinadas, mas os agricultores ou industriais deverão providenciar para que as se purifiquem, por qualquer processo, ou sigam o seu esgoto natural (grifos nossos).

Art. 112. Os agricultores ou industriais deverão indenizar a União, os Estados, os Municípios, as corporações ou os particulares que pelo favor concedido no caso do artigo antecedente, forem lesados (idem).

É nítida, na leitura dos artigos supra mencionados, a preocupação do legislador, àquela época, em proteger os recursos hídricos como meio de se proteger as atividades econômicas deles dependentes. Tanto assim o é que, textualmente o legislador prevê que, "se os interesses relevantes da agricultura ou da indústria o exigirem, e mediante expressa autorização administrativa, as águas poderão ser inquinadas”, caso em que, ficariam os agricultores ou industriais que assim procedessem, simplesmente obrigados a indenizar os lesados.

Desconsiderava o legislador àquela época, por completo, os efeitos deletérios e muitas vezes irremediáveis, de valor econômico inestimável, que tais inquinações poderiam causar ao meio ambiente como um todo. Não previa ali o legislador, que pudesse ocorrer o que hoje vem ocorrendo em muitos lugares de nosso país, de forma avassaladora, por conseqüência, exatamente, da poluição desmedida de nossas águas: a falta deste líquido em condições mínimas de consumo para as necessidades mais básicas do ser humano.

Somente com a Constituição de 1988, fruto do movimento ambientalista que passou a marcar o Brasil a partir da década de 70, é que o meio ambiente passou a ser considerado 
como UM BEM JURÍDICO EM SI MESMO CONSIDERADO, constituído pelo complexo de recursos naturais na formação do ecossistema indispensável à vida terrestre, levando o legislador a se conscientizar da necessidade de se criar normas de proteção efetivamente ambientais, ou seja, com o objetivo de se proteger o ecossistema em si, e não uma atividade econômica deste dependente. Ao ser o meio ambiente tratado como BEM JURÍDICO, conseqüência prática surge: Passa a ser objeto de direitos. Por conseguinte, são criados instrumentos hábeis à conferir efetiva proteção ao meio ambiente.

Não menos significante para a incrementação da proteção ao meio ambiente brasileiro é a expressão BEM DE USO COMUM DO POVO, empregada no texto constitucional, em seu artigo 225.

Consideram-se bens de uso comum do povo "todos aqueles destinados ao uso do povo sem nenhuma restrição, a não ser a da boa conduta, nos termos da lei, ou dos costumes, principalmente quanto à moral pública e aos bons costumes". ${ }^{11} \mathrm{Ou}$ ainda, segundo Maria Sylvia Di Pietro: "Consideram-se bens de uso comum do povo aqueles que, por determinação legal ou por sua própria natureza, podem ser utilizados por todos em igualdade de condições, sem necessidade de consentimento individualizado por parte da administração" 12

São exemplos de bens públicos os mares, florestas, o ar, rios, praias, ruas, praças, estradas, etc.

Os bens de uso comum do povo constituem uma das modalidades dos chamados bens do domínio público do Estado, que encontra nos chamados bens de uso especial, sua segunda modalidade.

Por se tratarem de bens que podem ser utilizados por qualquer pessoa do povo, coletiva ou individualmente, esta utilização se reveste em típico direito constitucional que, pela indeterminação dos agentes que podem exercê-lo, recebe o nome de DIREITO DIFUSO. A esta modalidade de direito, constitucionalmente assegurado, o legislador tratou de criar instrumentos eficazes para a garantia de seu exercício, como se verá nos tópicos adiante.

E, na medida em que o meio ambiente é classificado, no texto constitucional, como sendo um bem de uso comum do povo, a conseqüência imediata de tal classificação é a de que o meio ambiente se constitui como um típico direito difuso, merecendo as garantias e defesas a este reservadas, como veremos no item 1.4 infra.

\footnotetext{
11 FARIA, Edmur Ferreira de. Curso de Direito Administrativo Positivo. Belo Horizonte. Ed. Del Rey, 1999, $2^{\text {a }}$ ed. p. 401, como veremos abaixo.

12 DI PIETRO, Maria Sylvia Zanella. Direito Administrativo. 5. ed. - São Paulo - Ed. Atlas, 1994, p. 427
}

Revista da Faculdade Mineira de Direito, v.13, n. 25, jan./jun. 2010 - ISSN 1808-9429. 


\subsection{A Função Ambiental da Propriedade: a evolução do Direito de Propriedade como instrumento de proteção do meio ambiente}

O Direito, como fato social que é, encontra-se em permanente mutação, ao sabor dos ventos ideológicos de cada época.

Já vimos acima que, em outros tempos, o que ditava as normas ambientais, por exemplo, era mais a preocupação em se manter os recursos naturais indispensáveis à industrialização, do que necessariamente a preservação de um meio ambiente sadio.

Considerando-se que uma das dimensões do direito é de que este seja instrumento a ser utilizado para o controle das massas sociais, visando a garantir um mínimo de condições existenciais da vida em sociedade, valendo-se, para isto, da imposição de normas de conduta, é imprescindível, para que possamos compreender o espírito que norteou a elaboração destas, conhecermos o tempo em que foram elaboradas, bem como as correntes ideológicas que orientavam a sociedade à época.

É conveniente ainda, que não nos esqueçamos que, seja no Poder instituído pela via democrática, ou no Poder instituído pela força, em qualquer dos casos, inevitavelmente, será este Poder quem ditará as normas legais. Portanto, sociologicamente, não é incorreto afirmarmos que o Direito é o instrumento utilizado pelo Poder dominante para a imposição de sua ideologia.

O que legitima então o Poder democraticamente instituído é o fato de que este espelha a manifestação ideológica da maioria (ou ao menos deveria espelhar), enquanto que o Poder instituído pela força, é a manifestação ideológica de uma minoria.

A transformação pela qual passou o Direito de Propriedade no nosso ordenamento jurídico é um exemplo que ilustra de maneira singular a procedência do acima exposto.

Atendendo à nossa sugestão de analisarmos as correntes ideológicas vigentes à época da elaboração das normas, a fim de que conheçamos o seu espírito, passemos a analisar em que conjuntura se encontrava a sociedade brasileira quando da elaboração do nosso Código Civil de 1916, que tratava do Direito de Propriedade nos seus artigos 524 e segs.

O globo, no início do século XX, respirava em toda a sua intensidade os vapores da Revolução Industrial, iniciada na Inglaterra no final do século XIX. Àquela época, vigia entre os países ocidentais a filosofia do laissez faire, ícone do pensamento liberal (herança da Revolução Francesa), que encontrou no capitalismo emergente das indústrias, campo propício para o seu crescimento. Crescimento, este, que culminou com o fortalecimento do ideal capitalista nos governos de muitos Países. Dentre estes, o Brasil. 
Àquela época, havia ainda muito pouco tempo em que o Brasil deixara a condição de Império para se tornar República (1889).

A ordem jurídica encontrava-se em intenso período de transição. No âmbito do direito privado, por exemplo, o Brasil elaborava o seu primeiro Código Civil, cuja construção levara quase um século, culminando assim, com a revogação das chamadas Ordenações (codificação portuguesa aplicada no Brasil desde a sua fase imperial) ${ }^{13}$.

O primeiro Código Civil brasileiro, então, fora elaborado na efervescência do movimento industrial; no ápice da construção do novo capitalismo mundial; sob a égide de uma filosofia de Estado liberal. Liberalismo este aliás, que marcou os países ocidentais no início do século XX.

Diante disto, não é difícil chegarmos à conclusão que o nosso Código Civil de 1916 tratava-se de um documento legal de cunho altamente privatístico, em que desconsiderava por completo a presença do Estado nas relações privadas, tendo prevalência o princípio da vontade privada em detrimento do interesse público.

E o direito de propriedade, pelo conteúdo econômico imediato que lhe é intrínseco, seguramente foi um dos que recebeu, por parte de nossos legisladores, adeptos àquela filosofia liberal, a maior preocupação. Cuidou o legislador pátrio daquela época em assegurar o patrimônio particular, revestindo-o de instrumentos legais poderosos, hábeis a conferir ao proprietário o direito de usar, gozar, fruir, dispor e reivindicar de sua propriedade, como bem lhe aprouvesse, sem qualquer limitação ou condição externa, encontrando limites, portanto, apenas em sua vontade. O artigo 524 daquele diploma legal constituía, assim, a "pedra filosofal" sobre a qual foi construído todo o sistema de proteção ao direito de propriedade.

O direito de propriedade que foi apresentado à sociedade brasileira pelo Código Civil de 1916 representava desta forma, o ideal liberal daquela época, onde o que interessava era a proteção ao patrimônio particular, de modo que o proprietário pudesse contar com instrumentos eficazes o bastante para garantir-lhe toda a tranqüilidade no gozo de seus bens. Ainda que tal gozo implicasse na destruição da propriedade imobiliária, por exemplo, no desmatamento de grandes áreas, na derrubada de árvores, na caça de animais, etc. Se esta era a vontade do particular, era este o direito, então, que deveria ser protegido.

Note-se que não havia naquele diploma qualquer referência a limitações ao direito de propriedade. E este era tratado unicamente no âmbito do Direito Civil. Nem a Constituição da República vigente àquela época, nem qualquer outra que se seguiu (com exceção da 
Constituição da República de 1988) tratava do Direito de Propriedade, o que resultava em que tal direito sempre fosse tratado essencialmente como instituto do direito privado.

O pensamento liberal, entretanto, foi aos poucos perdendo forças. Começava a ficar claro que a ausência absoluta do Estado nas relações civis representava, em muitos casos, prejuízos, ou ao menos riscos, para a parte que, por motivos econômicos, políticos ou de qualquer outra ordem, fosse hipossuficiente em relação à outra.

Após a segunda metade do século XX, conforme já discutido no item 1.1 do presente capítulo, o globo começava a vivenciar uma nova mudança. Tiveram início, naquele período, movimentos sociais por todo o mundo (não é por coincidência que a evolução da consciência ambiental também eclode neste momento). Surgem novas categorias de direitos: são os direitos sociais, ou de terceira geração, representados pelos direitos coletivos e difusos, que trataremos no item 1.4 infra.

Nossa atual Constituição foi elaborada justamente no ápice deste momento de preocupação com o social. Por mais uma vez, a influência da ideologia de um momento histórico marcou o ordenamento legal: a nossa Constituição da República (chamada de Constituição Cidadã, pelo constituinte Ulysses Guimarães), é marcada pelo seu alto cunho social; pela preocupação com o coletivo.

E o texto constitucional de 1988 chamou para si a responsabilidade de tutelar o direito de propriedade. Isto porque, nas palavras de ROXANA CARDOSO:

\begin{abstract}
"O direito de propriedade, em sua concepção clássica, tem-se mostrado muitas vezes inadequado para os anseios da sociedade atual. Com a evolução dos direitos e a emergência de categorias como os direitos coletivos e difusos, os interesses da sociedade como um todo, mesmo que seus titulares não possam ser individualmente identificados, devem prevalecer sobre os interesses particulares que, desta forma, precisam ser adaptados às características deste momento histórico." (BORGES, Roxana Cardoso Brasileiro. Função Ambiental da Propriedade. São Paulo. Ed. Revista dos Tribunais. 1998. Vol. 9, p. 68)
\end{abstract}

Disto resulta que atualmente não se pode mais conceber a propriedade como sendo um regime jurídico meramente subordinado ao Direito Civil. Ao contrário:

“(...) em verdade, o regime jurídico da propriedade tem seu fundamento na Constituição. Esta garante o direito de propriedade, desde que ela atenda a sua função social (art. $5^{\circ}$, XXII e XXIII). (...) Significa isso que o Direito Civil já não disciplina mais a propriedade, mas tão somente regula as relações civis a ela pertinentes. Assim, só valem no âmbito das relações civis as disposições do Código Civil que estabelecem as faculdades de usar, gozar e dispor de bens (art. 524), a plenitude da propriedade (art. 525), o caráter exclusivo e ilimitado do domínio (art. 527), etc." (grifos nossos). (SILVA, José Afonso da. Direito Urbanístico Brasileiro. P. 62)

Ou ainda: 
“Com o advento da Constituição da República de 1988 o direito de propriedade deixa de ter sua regulamentação exclusivamente privatista, baseada no Código Civil, e passa a ser um direito privado de interesse público, sendo as regras para o seu exercício determinadas pelo Direito Público e pelo Direito Privado. Este processo de publicização do direito de propriedade é fundamental para a implementação da legislação referente à proteção do meio ambiente, que impõe limites ao exercício daquele direito". (BORGES, Roxana Cardoso Brasileiro. Função Ambiental da Propriedade. São Paulo. Ed. Revista dos Tribunais. 1998. Vol. 9, p. 69)

Note-se, portanto, que a Constituição tratou de instituir limites àquele direito que o Código Civil garantia como pleno ao seu titular. A Constituição de 88 garante a propriedade, desde que esta atenda a sua função social. Assim, não pode mais o proprietário gozar de sua propriedade até o ponto de trazer prejuízos à coletividade. Há de se atender a sua função social. E um dos matizes da função social da propriedade é a chamada função ambiental da propriedade, resguardada no artigo 170, III de nossa Constituição. Valendo-nos mais uma vez das palavras de ROXANA CARDOSO:

\begin{abstract}
"Ao se tentar demonstrar o conteúdo da função ambiental da propriedade, esta é considerada como um elemento da função social da propriedade, que é um conceito anterior e de alcance mais amplo que a função atribuída àquele instituto advinda da necessidade de manutenção de um meio ambiente equilibrado. Embora estas duas categorias não sejam antagônicas - ao contrário, são complementares - , tem-se a função ambiental da propriedade como uma característica marcante da Constituição de 1988, que considera a problemática ambiental parte da social e vice-versa.

(...) a sociedade contemporânea, com suas necessidades de manutenção de um meio ambiente equilibrado e da implantação de um modelo de desenvolvimento sustentável, vem transformando, aos poucos, a concepção privatista do direito de propriedade em direção à propriedade como sendo um direito-dever" (op. cit. p. 67)
\end{abstract}

Vê-se, portanto, que a função ambiental da propriedade constitui o próprio conteúdo deste direito.

Diante da preocupação de se garantir a proteção do meio ambiente, a propriedade é um dos institutos jurídicos que mais claramente é afetado pela legislação ambiental ${ }^{14}$. O clássico conceito de propriedade vem sofrendo alterações para que este direito seja compatível com a preocupação ambiental. Prova maior disto é o novo trato que o Código Civil dedicou à matéria.

Tendo sido elaborado e entrando em vigor em período histórico marcado pelas mesmas preocupações sociais que marcaram a nossa Constituição de 1988, o novo Código Civil, em vigor desde 10 de janeiro de 2003, deu novo tratamento ao direito de propriedade, recepcionando o trato constitucional.

14 BORGES, Roxana Cardoso Brasileiro. Função Ambiental da Propriedade. São Paulo. Ed. Revista dos Tribunais. 1998. Vol. 9, p. 68

Revista da Faculdade Mineira de Direito, v.13, n. 25, jan./jun. 2010 - ISSN 1808-9429. 
Cuidou o novo Código Civil, em seu artigo 1228, de remodelar o antigo artigo 524 do Código Civil de 1916, ao acrescentar cinco parágrafos de cunho eminentemente restritivo ao direito de propriedade. Note-se, portanto, que o artigo 1228 do novo Código Civil traz em seu bojo a preocupação com o social que não existia no artigo 524 do antigo Código, impondo limitações ao direito de propriedade, absolutamente impensáveis àquela época.

Tal tratamento, definitivamente, retira do direito de propriedade o cunho privatístico que lhe marcava no antigo ordenamento civil e lhe confere ares mais sociais, em sintonia com o texto constitucional.

\subsection{Os Direitos difusos e coletivos e a proteção ao meio ambiente}

Dentre vários fatores que fortaleceram a eclosão da preocupação ambiental no Brasil e possibilitaram o seu crescimento nos mais diversos setores da sociedade brasileira, ganha destaque a construção jurídica dos chamados DIREITOS ou INTERESSES METAINDIVIDUAIS ou TRANSINDIVIDUAIS, lançados no plano constitucional brasileiro por intermédio do artigo 129, III da Constituição da República de 1988 e conceituados legalmente na Lei número 8.078/90, em seu artigo 81, incisos I, II e III, nos seguintes termos:

\footnotetext{
Art. 81 - A defesa dos interesses e direitos dos consumidores e das vítimas poderá ser exercida em juízo individualmente, ou a título coletivo.

Parágrafo único. A defesa coletiva será exercida quando se tratar de:

I - interesses ou direitos difusos, assim entendidos, para efeitos deste código, os transindividuais, de natureza indivisível, de que sejam titulares pessoas indeterminadas e ligadas por circunstâncias de fato;

II - interesses ou direitos coletivos, assim entendidos, para efeitos deste código, os transindividuais, de natureza indivisível de que seja titular grupo, categoria ou classe de pessoas ligadas entre si ou com a parte contrária por uma relação jurídica base;

III - interesses ou direitos individuais homogêneos, assim entendidos os decorrentes de origem comum (grifos nossos).
}

\subsubsection{O meio ambiente como direito difuso e sua tutela na Constituição da República de 1988}

A Constituição brasileira de 1988 reconheceu o meio ambiente como sendo um interesse difuso, ou seja: interesse que pertence a todos os homens, independentemente do grupo, órgão ou associação a que pertença. "Prova disso é o local de inserção das normas atinentes ao meio ambiente na Constituição da República: "Título VIII - Da Ordem Social (arts. 193 a 232). Ora. Se importa à ordem social, é coletivo" ${ }^{15}$ (vale lembrar aqui, que o autor desta nota considera os termos coletivo e difuso como sinônimos).

15 MORAES, Luís Carlos Silva de. Curso de Direito Ambiental. São Paulo. Ed. Atlas. 2001, p. 15

Revista da Faculdade Mineira de Direito, v.13, n. 25, jan./jun. 2010 - ISSN 1808-9429. 
Para esta classe de direitos/interesses (os metaindividuais), justamente por serem manifestação da vontade geral, o legislador infra-constitucional já havia criado, anteriormente à Constituição de 88 , instrumento de defesa dotado de singular poder para a sua proteção, e que atribuía legitimidade para o seu exercício a todas as entidades que, de uma forma ou de outra, representassem a vontade da coletividade. Trata-se da AÇÃO CIVIL PÚBLICA, recepcionada pela Constituição da República, em especial, no artigo 129, inciso III, que atribui ao Ministério Público a função institucional de promover a Ação Civil Pública, para a proteção do meio ambiente e de outros interesses difusos.

\subsubsection{A defesa dos interesses difusos como exercício da cidadania}

Por se tratar de categoria de direitos relativamente recente em nossa história nacional, os interesses metaindividuais são vistos, pela maioria dos cidadãos comuns, de forma distorcida e, por que não dizer, equivocada.

Via de regra, o cidadão comum não se vê titular de um interesse metaindividual. No que diz respeito, especificamente aos direitos coletivos, a idéia que vigora no senso comum é a de que estes interesses devem ser defendidos e exercidos por associações de classe, sindicatos, associação de moradores, Ministério Público, etc., Enfim, entes despersonificados ou, usando de termo já anteriormente empregado neste trabalho, por "corpos intermediários", que não o indivíduo ou o Estado, mas jamais pelo cidadão comum.

Tal ponto de vista, inegavelmente, se constitui em álibi perfeito para encobrir a natural acomodação do cidadão comum no que tange à proteção de seus interesses/direitos.

Ora. Se esta acomodação, em alguma medida, tem o fundamento de sua existência na natureza dos interesses coletivos (pelo fato de que a legitimidade do exercício e da defesa destes direitos está ligada à idéia de entes coletivos organizados), a mesma acomodação não pode viger no que diz respeito aos direitos/interesses difusos. Estes, por sua própria natureza, são direitos em que o fim específico perseguido não se encontra vinculado a qualquer grupo determinado/determinável de pessoas mas, ao contrário, encontra-se difuso; espalhado, entre todos os brasileiros. Este fim específico, portanto, poderá ser perseguido por várias pessoas, individual ou coletivamente, sem que tenha de haver, para tanto, qualquer vinculação a este ou aquele grupo, órgão ou associação.

Felizmente, há alguns anos vem crescendo em nosso país a conscientização do cidadão de que, exigir os seus direitos individuais constitui-se no próprio exercício da cidadania. E, quanto mais pleno é o exercício da cidadania, mais forte se constitui o Estado. 
Entretanto, o exercício da cidadania plena encontra obstáculo na noção deficiente que o cidadão comum possui da largueza de seus direitos, que os entende apenas enquanto na órbita individual.

O conceito de Direitos Difusos sequer é conhecido pelo cidadão comum. Que dirá, então, o meio de exercê-los?

Entender, portanto, o que vem a ser um interesse difuso e saber como exercê-lo, constitui passo imprescindível para o fortalecimento do próprio Estado por mãos de seu povo.

No que tange, especificamente ao meio ambiente, é absolutamente necessário que este seja compreendido como sendo um direito de todos, que deve ser defendido por qualquer cidadão, independentemente de grupos ou associações, distribuindo entre a sociedade o peso do trabalho que, hoje em dia, recai apenas nos ombros do Ministério Público. Não por ser o único legitimado a exercer a proteção do Meio Ambiente, mas por simples ausência de sujeitos que também chamem para si tal prerrogativa.

É absolutamente necessário que se crie a consciência de que a defesa do Meio Ambiente se constitui na defesa de nosso maior patrimônio e de nosso próprio Estado e que, por isto mesmo, a sua proteção se constitui em direito-dever irrenunciável de cada um.

Afinal, como dispõe o artigo 225 da Constituição da República:

\footnotetext{
"Todos têm direito ao meio ambiente ecologicamente equilibrado, bem de uso comum do povo e essencial à sadia qualidade de vida, impondo-se ao Poder Público e à coletividade o dever de defendê-lo e preservá-lo para as presentes e futuras gerações" (grifos nossos).
}

Há nisso, então, um poder-dever do Estado e dos cidadãos, cooperativamente.

A Ação Popular e Ação Civil Pública não podem (por inércia dos cidadãos brasileiros) constituírem em instrumentos poderosos de combate às mazelas da sociedade, de uso exclusivo do Ministério Público.

Urge a necessidade da população brasileira acordar de sua letargia secular, arregaçarem suas mangas e, EFETIVAMENTE, defender o nosso maior patrimônio: o nosso meio ambiente.

\begin{abstract}
This study aims to examine the evolution of laws in which environment has gone through. It has been our matter of consideration to demonstrate that environmental concern was only raised in Brazil in the 60's. Yet, thanks to international pressures the world has suffered, especially after Club of Rome was founded in 1968 and raised considerable public attention in 1972.
\end{abstract}


In Brazil, a factor of high importance in the evolution of environmental protection was its promotion to the status of "common properties", it means that, it has been considered a legal issue. Furthermore, in Constitution of Brazil ratified in 1988, it received the treatment as diffuse interest good.

Thus, the possibility of defense of the environment is not attached to the Prosecutor, but it transcends to all those who wish to put up its defense, which would contribute to greater scrutiny and care with environmental issues.

Unfortunately, however, the vast majority of Brazilian people have not been aware of the fact that taking care of common wealth is taking care of ours.

Hope this work will help people be aware how important the collective protection of the environment is.

Keywords: Eviroment, Constitution, Public Action, Citizenship.

\section{REFERÊNCIAS}

AMARAL, Diogo Freitas, Direito do Ambiente. Oeiras: INA, 1994.

AMARAL, Lídia Miranda de Lima. Mediação e Arbitragem: uma solução para os conflitos trabalhistas no Brasil. São Paulo: LTr, 1994

ARAÚJO, Adriano L., SILVEIRA, Anarita A., DYTZ, Karen I. O Instituto da Mediação in Revista Doutrina. Rio de Janeiro: Instituto de Direito, vol. III, 1997

BARACHO JÚNIOR, José Alfredo de Oliveira. Responsabilidade Civil por Dano ao Meio Ambiente. Belo Horizonte. Ed. Del Rey.

BASTOS, Celso. Curso de Direito Constitucional. 16. ed. São Paulo. Saraiva, 1995.

BENJAMIN, Antônio Herman V., Responsabilidade Civil pelo Dano Ambiental in Revista de Direito Ambiental, São Paulo, Ed. Revista dos Tribunais, ano 3, n. 09, janeiro-março de 1998

Objetivos do Direito Ambiental in Lusíada - Revista de Ciência e Cultura, série de Direito, número especial (Actas do I Congresso Internacional de Direito do Ambiente da Universidade Lusíada-Porto), 1996

BORGES, Roxana Cardoso Brasileiro. Função Ambiental da Propriedade. São Paulo. Ed. Revista dos Tribunais. 1998

BRASIL. Constituição da República Federativa do Brasil. 29. ed. atual. e ampl. São Paulo. Saraiva. 2002.

CAPPELLETTI, Mauro. Appunti sulla tutla giurisdizionale di interessi collettivi o diffusi. Giurisprudenza italiana, 1975.

CAVALIERI FILHO. Sérgio. Programa de Responsabilidade Civil. São Paulo, Malheiros, 1996.

Código Brasileiro de Defesa do Consumidor: comentado pelos autores do anteprojeto / Ada Pellegrini Grinover ...[et al.]. - 7. ed. - Rio de Janeiro: Forense Universitária, 2001

Revista da Faculdade Mineira de Direito, v.13, n. 25, jan./jun. 2010 - ISSN 1808-9429. 
CRETELla JÚNIOR. José. Curso de Direito Romano: o Direito Romano e o Direito Civil brasileiro. 13. ed. rev. e ampl. Rio de Janeiro. Forense. 1991.

CRUZ E TUCCI, José Rogério Lauria. Ação Civil Pública: abusiva utilização pelo Ministério Público e distorção pelo Poder Judiciário. In Revista Síntese de Direito Civil e Processo Civil, - nº 18 - Jul-Ago/2002 - doutrina. 